\title{
Methanol Stem Bark Extract of Ficus platyphylla Protects Against Carbon Tetrachloride-Induced Liver Damage in Wistar Rats
}

\author{
${ }^{1}$ C. J. Ugwah-Oguejiofor, ${ }^{1}$ S. G. Ibrahim, ${ }^{2}$ H. E. Mshelia, ${ }^{3}$ U. Mohammed and ${ }^{1}$ I. M. Adebisi \\ 1Department of Pharmacology and Toxicology, Faculty of Pharmaceutical Sciences, Usmanu Danfodiyo University, Sokoto, Nigeria \\ 2Department of Pharmacognosy and Ethnopharmacy, Faculty of Pharmaceutical Sciences, Usmanu Danfodiyo University, Sokoto, \\ Nigeria \\ 3Department of Morbid Anatomy and Forensic Medicine, Histopathology, Usmanu Danfodiyo University and Teaching Hospital, \\ Sokoto, Nigeria
}

[Corresponding Author: E-mail: nenye789@yahoo.com]

\section{ABSTRACT}

Ficus platyphylla (Gutta percha tree) is used in Nigerian traditional medicine for treating pain and psychosis. This study evaluated the protective effect of methanol stem bark extract of Ficus platyhylla (MEFP) against carbon tetrachloride $\left(\mathrm{CCl}_{4}\right)$-induced liver injury in Wistar rats. Rats were allotted into six groups namely normal control, negative control, standard drug (silymarin) and extract treated (100, 200 and $400 \mathrm{mg} / \mathrm{kg} \mathrm{p.0.}$ respectively) groups. Treatment was administered for 7 days. Animals in groups II-VI received a single dose of $\mathrm{CCl}_{4}(1: 1)$ p.o. in olive oil at $1.5 \mathrm{ml} / \mathrm{kg}$ body weight after last treatment. Experimental rats were sacrificed after 24 hours of $\mathrm{CCl}_{4}$ administration and blood samples collected for determination of alanine aminotransferase (ALT) and aspartate aminotransferase (AST) activities. Supernatant of liver homogenate was used to determine activities of catalase (CAT), superoxide dismutase (SOD) and glutathione peroxidase (GPx). Results indicate increased activities $(p<0.05)$ in CAT, SOD and GPx in samples of MEFP treated rats while levels of ALT and AST in serum samples of treated groups differ significantly $(p<0.05)$ when compared with negative control group (Group III). Treatment with methanol stem bark extract of Ficus platyphylla may have offered protection against $\mathrm{CCl}_{4}$ induced liver damage in experimental rats.

Keywords: Ficus platyphylla, Gutta percha Tree, Liver Damage, Carbon Tetrachloride, Wistar Rats

\section{INTRODUCTION}

The liver is the body organ saddled with the task of metabolism and detoxification of drugs and xenobiotics (Ugwah-Oguejiofor and Ugwah, 2018; Alrashood et al., 2020). Injury to the liver may cause anomalies in its general metabolic functions resulting in various liver disorders. These disorders could be transient or life threatening. Certain medicines and chemicals such as excess alcohol intake, intake of certain drugs, exposure to various toxin and pollutants have been implicated in diseases resulting from liver injury (lqbal et al., 2018; Huang et al., 2020). Liver diseases are the fifth most common cause of death and the second major cause of death amongst all digestive diseases (Agada et al., 2020). They cause approximately 2 million deaths annually worldwide (Asrani et al., 2019).
In Nigeria, its incidence is high with varying degree of prevalence reported in different geopolitical areas across the country. According to the World Health Organisation (WHO) data published in 2018, death from liver disease in Nigeria was placed at 60,044 or $3.10 \%$ of total deaths and thereby ranking Nigeria the second in the world (Stanaway et al., 2018). This causes a challenge to the already burdened health care delivery in the country. Currently, there are no approved, effective drugs for treating liver diseases (Chen et al., 2019), and the effectiveness of the non-pharmacological approaches are minimal (Svistunov et al., 2018). Therefore, it is imperative that urgent medical attention be given to the search for pharmacological agents for the treatment of liver disease. A variety of medicinal plants are proposed for use in the treatment of liver toxicity. Ficus platyphylla (Gutta percha tree) is one of 
such plants whose stem bark extract is used traditionally for the treatment of liver diseases (Kankara, et al., 2018; Nnamudi et al., 2020).

Ficus platyphylla Del. Holl (Moraceae), commonly referred to as the Gutta percha tree, is a large deciduous tree widely distributed in the savannah regions along the West African coast. It is known as gamii among the Hausas in Northern Nigeria. Various preparations of the plant are used to treat several diseases including psychosis, infertility, malaria, and CNS disorders (Ugwah-Oguejiofor et al., 2011; Chindo et al., 2016). Previously, studies on this plant have revealed its central nervous system effect, antimalarial and gastrointestinal activities (Shittu et al., 2011; Chindo et al., 2014). Its methanol stem bark extract (MEFP) has been investigated for several pharmacological activities. Ficus species have been shown to possess hepatoprotective effect against human hepatocellular carcinoma cells (Al-Musayeib et al., 2017). In this study, the aim was to examine the protective action of MEFP in $\mathrm{CCl}_{4}$-induced liver toxicity in Wistar rats.

\section{MATERIALS AND METHODS}

\section{Plant Collection and Identification}

Ficus platyphylla stem bark was obtained from Sokoto south Forestry Zone 1, Sokoto State, Nigeria, in the month of March 2017. Initial identification and authentication of the plant was done by Dr. H. E. Mshelia of Faculty of Pharmaceutical Sciences, Usmanu Danfodiyo University, Sokoto. A voucher specimen PCG/UDUS/MORA/003 was safely kept in the herbarium of the same Faculty for future reference.

\section{Preparation of Plant Material and Extraction}

The stem bark of Ficus platyphylla plant was cleaned and air dried to constant weight. It was then pulverized mechanically using mortar and pestle into a dry powder and weighed. The powder $(500 \mathrm{~g})$ was extracted with $1.5 \mathrm{~L}$ of $70 \%$ methanol using cold maceration method for 48 hours. The resultant mixture was filtered, and the filtrate evaporated to dryness in an oven set at $40^{\circ} \mathrm{C}$. The percentage yield was calculated as follows:

$\%$ yield $=W_{2} / W_{1} * 100$

Where $W_{2}=$ Weight of extract $(g) ; W_{1}=$ Weight of plant material $(\mathrm{g})$

\section{Chemicals and Reagents}

Some chemicals and reagents used for this study include methanol, L-Ascorbic acid, DPPH, Molisch reagent, Tris buffer (pH7.7), L-Aspartate, MDH, LDH, Sodium hydroxide, Sodium Azide, 2Oxaloacetate, and L-Alanine.Kits for biochemical analyses of some liver marker enzymes were purchased from Sigma-Aldrich (Sigma-Aldrich, St. Louis, MO, USA).

\section{Determination of Free Radical Scavenging Activity of Ficus Platyphylla Methanol Stem Bark Extract}

The ability of MEFP to scavenge 2, 2- diphenyl-1picrylhydrazyl (DPPH) was determined following the method of Goyal et al. (2010). A stock concentration of $125 \mathrm{mg} / \mathrm{ml}$ MEFP in methanol was prepared. Serial dilution was carried out to obtain various concentrations $(6.25,3.13,1.56$, 0.78 and $0.39 \mathrm{mg} / \mathrm{ml}$ ). Exactly $1 \mathrm{ml}$ of freshly prepared DPPH was added to the test tubes containing the different concentrations of MEFP mixed and incubated at $20{ }^{\circ} \mathrm{C}$ for $30 \mathrm{~min}$. The absorbance for both MEFP and standard ascorbic acid were taken at $517 \mathrm{~nm}$ and the percentage inhibition calculated using the relationship:

$\%$ of radical Scavenging activity $=A \mathrm{As}_{\text {control }}$ Abs sample $/ \mathrm{Abs}_{\text {control }} \times 100$

Determination of Total Phenolic content of Ficus Platyphylla Methanol Stem Bark Extract The total phenolic content of MEFP was determined using Folin-Ciocalteu reagent (Kalantar et al., 2018). After preparation of different concentrations of MEFP, $0.5 \mathrm{ml}$ of FolinCiocalteu reagent (previously diluted with water $1: 10 \mathrm{v} / \mathrm{v}$ ) and $0.4 \mathrm{ml}$ of $7.5 \%$ sodium carbonate were added. The tubes were mixed gently for 15 $\mathrm{s}$ and allowed to stand for $30 \mathrm{~min}$ at $40{ }^{\circ} \mathrm{C}$ for colour development. The absorbance of the resulting colour complex was measured at 765 
$\mathrm{nm}$. The total phenol content was expressed in milligrams of gallic acid equivalents per gram of MEFP.

\section{Experimental Animals}

Male Wistar rats, weighing 166-188 g were acquired from ABU-Zaria, animal facility centre. They were allowed to acclimatize for 2 weeks in well-built cages kept in a hygienic environment with housing condition maintained at $25 \pm 2{ }^{\circ} \mathrm{C}$ at 12-hour day/night cycles before starting the experiment. The animals were allowed access to feed and water ad libitum. The study protocol was approved by the animal research ethical committee of the Department of Pharmacology and Toxicology UDUS (PTAC/Fp/(ME)/OT/26-20). The care and handling of the animals were according to the established public health guidelines (NIH, 1985).

\section{Grouping of Experimental Rats and Induction of liver injury}

Six experimental groups comprising 6 rats each were grouped as follows: Group I served as the normal healthy (positive) control group and was given $5 \mathrm{ml} / \mathrm{kg}$ of normal saline. Groups II and III were the negative and standard drug treated groups and received $5 \mathrm{ml} / \mathrm{kg}$ normal saline and $100 \mathrm{mg} / \mathrm{kg}$ silymarin, respectively (UgwahOguejiofor and Ugwah, 2018). Groups IV - VI were administered $100 \mathrm{mg} / \mathrm{kg}, 200 \mathrm{mg} / \mathrm{kg}$ and $400 \mathrm{mg} / \mathrm{kg}$ MEFP, respectively. Treatment lasted for 7 days after which a single dose of $1.5 \mathrm{ml} / \mathrm{kg}$ $\mathrm{CCl}_{4}$ in olive oil (1:1) p.o. was given to the rats in Groups II-VI. After 24 hours of $\mathrm{CCl}_{4}$ administration, rats were sacrificed and blood samples collected. The livers were harvested, weighed and divided into two parts. One part was fixed in 10\% phosphate-buffered neutral formalin and used for histopathological assessment while the other part was homogenised, and prepared for tissue antioxidant enzyme assays.

\section{Biochemical Assays}

The collected blood samples were centrifuged at $4000 \times \mathrm{g}$ for 10 minutes. Sera obtained were pipetted into labelled tubes for estimation of alanine aminotransferase (ALT) and aspartate aminotransferase (AST) enzymes using the method of Reitman and Frankel (1957). For antioxidant enzyme assays, preserved liver tissue as described was rinsed with phosphate buffered saline (PBS) solution $(\mathrm{pH} 7.4)$ to remove traces of blood cells and clots. The tissue was homogenised in $10 \mathrm{ml}$ of cold buffer ( $50 \mathrm{mM}$ Tris$\mathrm{HCl} \mathrm{pH} \mathrm{7.5,} 5 \mathrm{mmol}$ EDTA, and $1 \mathrm{mmol}$ DTT) per gram tissue. The homogenate was centrifuged at $4000 \mathrm{x} \mathrm{g}$ for 15 minutes. Estimation of catalase (CAT), superoxide dismutase (SOD) and glutathione peroxidase (GPx) activities were carried out using the supernatant. The tests were carried out using the respective kits and following manufacturer's specifications.

\section{Histopathological Examination of liver Tissues of Experimental Rats}

The fixed liver tissues were dehydrated in an ascending series of alcohol, cleared in xylene, and embedded in paraffin wax $\left(60^{\circ} \mathrm{C}\right.$ melting point). They were sectioned serially ( $5 \mu \mathrm{m}$ thick) and stained using haematoxylin and eosin dyes (H\&E). The sections were then mounted on a photomicroscope (Carl Zeiss Microscope) and examined at Magnification x 100 .

\section{Data Analysis}

Data were presented as mean \pm standard error of mean (SEM). The results were analysed using Graph Pad Prism version 6 software. Multiple comparison of means amongst groups were made using one-way analysis of variance (ANOVA) Tukey post hoc test. Differences at $p<0.05$ were considered statistically significant. $\mathrm{IC}_{50}$ value for both MEFP and ascorbic acid were calculated using GraphPad Prism version 6

\section{Results}

Yield and Total Phenolic Content of Ficus Platyphylla Methanol Stem Bark Extract

A percentage yield of MEFP was observed to be $11.4 \% \mathrm{w} / \mathrm{w}$ while the total phenolic content was found to be $7.99 \mathrm{mg} / \mathrm{ml}$ expressed as gallic equivalent (GAE/g extract). 
Effect of MEFP on DPPH Scavenging Activity The MEFP DPPH scavenging activity showed that there was absorption band at $517 \mathrm{~nm}$ in visible region and DPPH solution decolourized as the colour changes from deep violet to light yellow. The percentage inhibition of MEFP and ascorbic acid are presented in Table 1. While the $\mathrm{IC}_{50}$ of MEFP was $3.77 \mu \mathrm{g} / \mathrm{mL}$, that of ascorbic acid was $12.88 \mu \mathrm{g} / \mathrm{mL}$

Table 1: DPPH scavenging activity of MEFP and ascorbic acid

\begin{tabular}{ccc}
\hline $\begin{array}{c}\text { CONCENTRATION } \\
(\mathrm{mg} / \mathrm{mL})\end{array}$ & $\begin{array}{c}\% \\
\text { FOR MEFP }\end{array}$ & $\begin{array}{c}\text { INHIBITION } \\
\text { ASCORBIC ACID }\end{array}$ \\
\hline 6.25 & 91.51 & 97.37 \\
3.13 & 90.43 & 96.99 \\
1.56 & 87.05 & 96.85 \\
0.78 & 83.49 & 95.81 \\
0.39 & 63.79 & 91.18 \\
\hline
\end{tabular}

MEFP IC ${ }_{50}=3.77 \mu \mathrm{g} / \mathrm{mL} ;$ Ascorbic acid IC $50=12.88 \mu \mathrm{g} / \mathrm{mL}$

\section{Effect of MEFP on Liver Function Parameters}

Administration of $\mathrm{CCl}_{4}$ in the rats produced an increase in ALT and AST (Figure 1). Pretreatment with MEFP at doses of 100 and 400 $\mathrm{mg} / \mathrm{kg}$ inhibited the $\mathrm{CCl}_{4}$-induced oxidative stress by significantly $(p<0.05)$ decreasing the serum levels of ALT and AST when compared to the negative $\left(\mathrm{CCl}_{4}\right)$ control group.

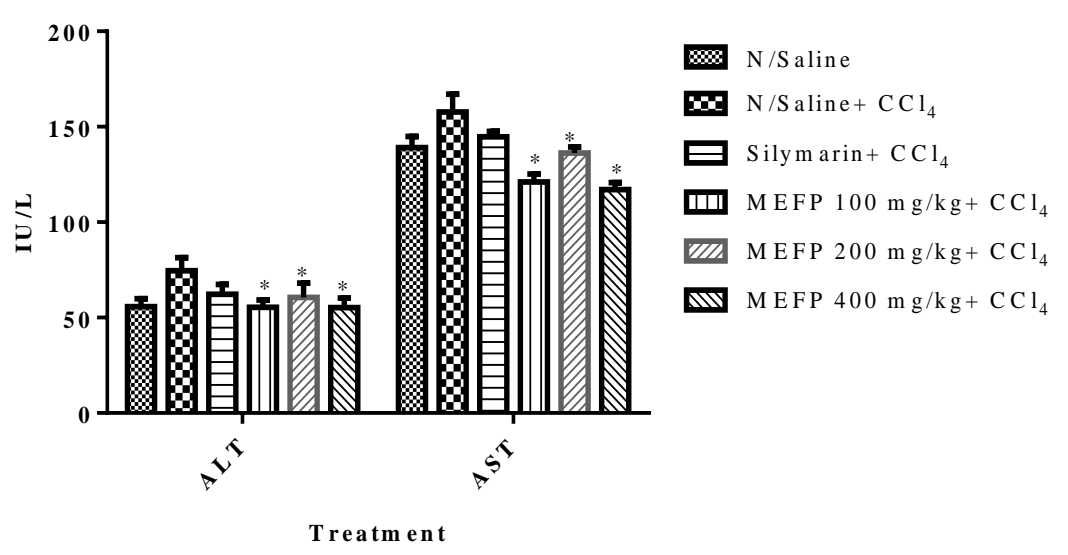

Figure 1: Effect of methanol extract of stem bark of Ficus platyphylla (MEFP) on liver enzymes ${ }^{*} \mathrm{p}<0.05$ when compared to $\mathrm{CCl}_{4}$ control group, $\mathrm{n}=6, \mathrm{ALT}=$ alanine aminotransferase, AST=aspartate aminotransferase

\section{Effect of MEFP on Liver Antioxidant Enzymes Activities}

Administration of $\mathrm{CCl}_{4}$ produced lower activity of CAT. MEFP administration at all dose levels caused an increase in CAT activity in the liver enzymes assay which was significantly $(p<0.05)$ higher than the negative control group (Figure 2). The extract in a dose dependent manner caused a rise in the SOD activity which was initially decreased as a result of $\mathrm{CCl} 4$ administration. The 
significant increase was more at the doses of 200 and $400 \mathrm{mg} / \mathrm{kg}$ than at $100 \mathrm{mg} / \mathrm{kg}$ treatment groups when compared with the negative control group (Figure 3). Pretreatment of the animals with MEFP at all dose levels showed a significant $(p<0.05)$ increase in hepatic GPx activity with respect to the negative control group (Figure 4).

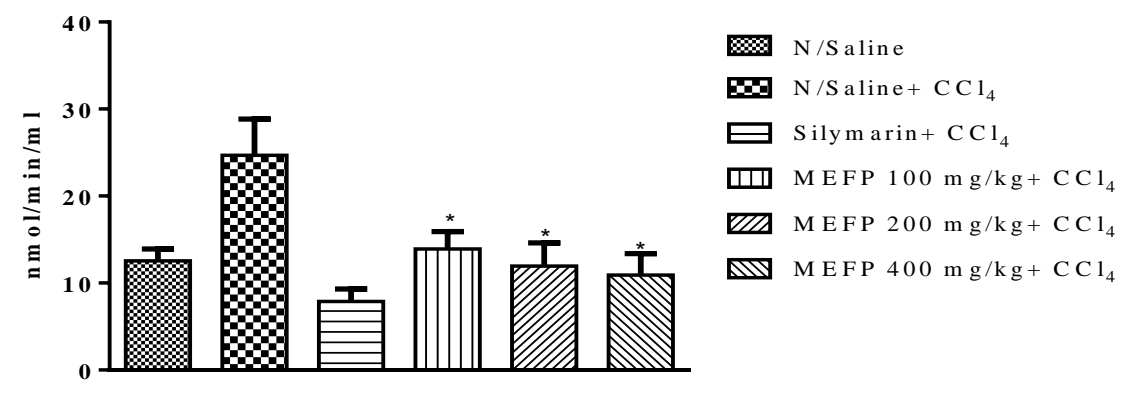

Figure 2: Effect of methanol extract of stem bark of Ficus platyphylla (MEFP) on catalase (CAT) activity

${ }^{*} p<0.05$ compared with $\mathrm{CCl}_{4}$ group, $\mathrm{n}=6$

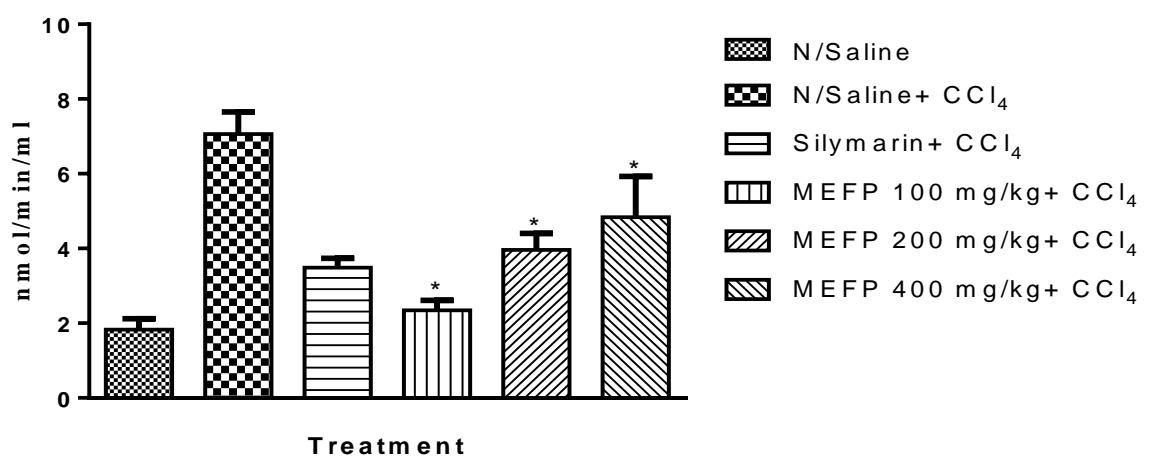

Figure 3: Effect of methanol extract of stem bark of Ficus platyphylla (MEFP) on superoxide dismutase (SOD) activity ${ }^{*} p<0.05$ compared with $\mathrm{CCl}_{4}$ group, $\mathrm{n}=6$

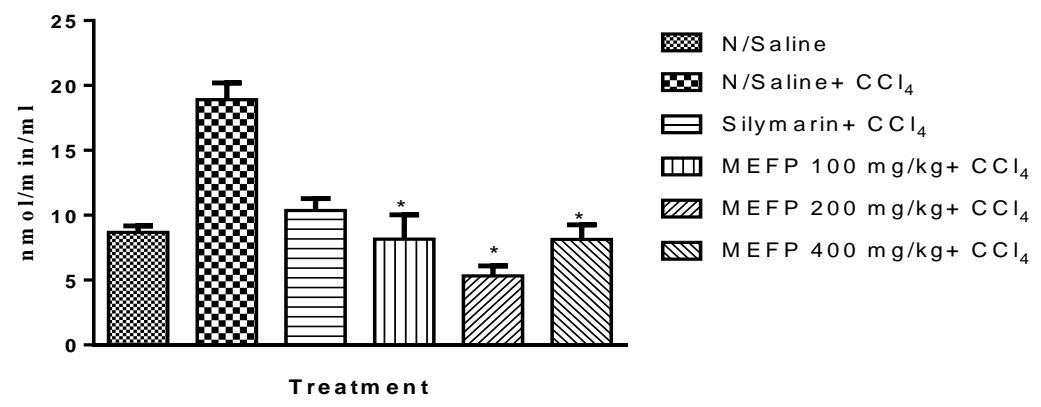

Figure 4: Effect of methanol extract of stem bark of Ficus platyphylla (MEFP) on glutathione peroxidase (GPx) activity ${ }^{*} p<0.05$ compared with $\mathrm{CCl}_{4}$ group, $\mathrm{n}=6$ 


\section{Histopathology of the liver of MEFP treated rats}

The histopathological examination of the liver tissues of both the controls and treated animals are shown in Figures $5 \mathrm{~A}-\mathrm{F}$. The liver of rats in the positive control group showed hepatocytes with normal architecture (Figure 5A), whereas the liver of rats in the $\mathrm{CCl}_{4}$ control group, showed distorted hepatic architecture as evident by intense ballooning and necrosis of hepatocytes (Figure
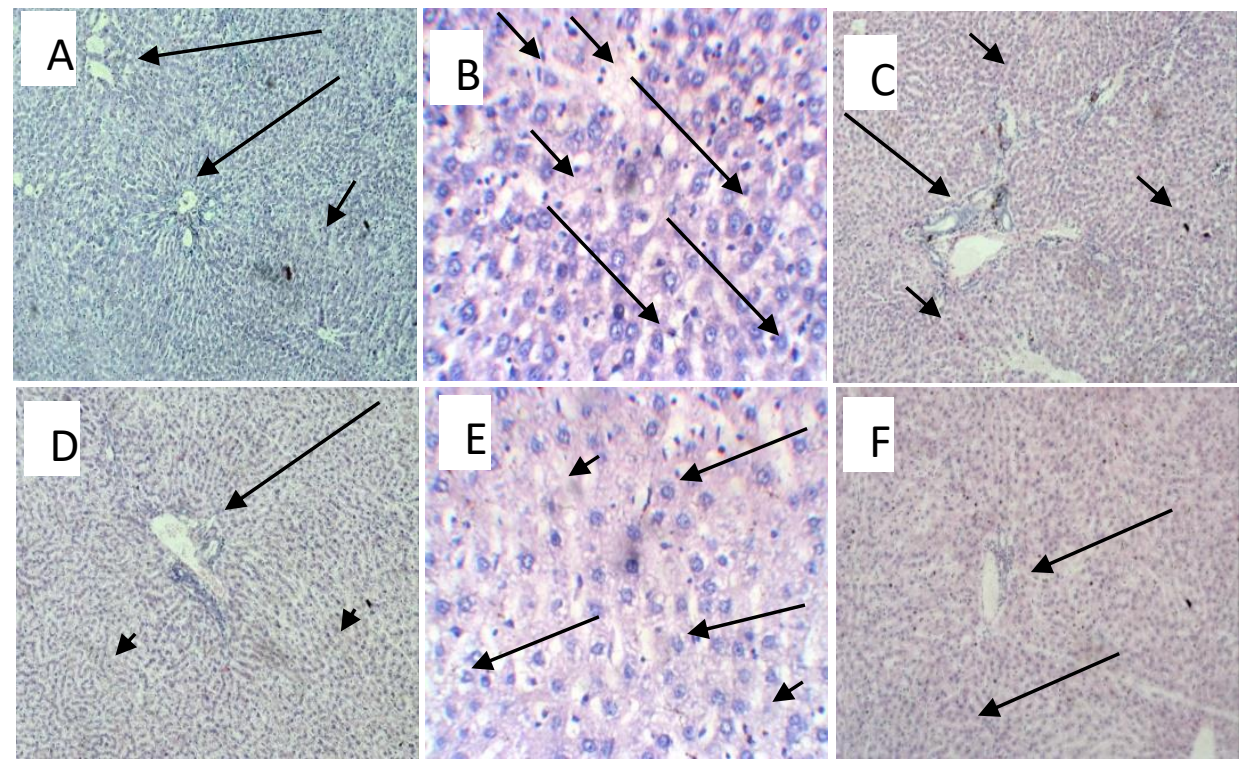

Figure 5: Micrograph section of hepatic tissue of MEFP treated rats exposed to $\mathrm{CCl}_{4}$ intoxication Key: (A) (Group I) Normal saline treated group - well preserved hepatic architecture, portal tract (Long arrow) and normal hepatocyte (short arrow); (B) (Group II) $\mathrm{CCl}_{4}$ treated group - Distorted hepatic architecture evidence by Ballooning +++ (Long arrow) and Necrosis of the hepatocytes +++ (arrow); (C) (Group III)Silymarin treated group for 7 days: Preserved hepatic architecture, portal tract (long arrow) and sinusoid (short arrow) (D)(Group IV)CCl $4+$ methanolic stem bark extract of Ficus platyphylla $100 \mathrm{mg} / \mathrm{kg}$ for 7 days: Ballooning ++, hepatocytes vacuoles ++ (micro vesicular steatosis) (short arrow), preserved architecture and portal tract (long arrow) (E)(Group V) $\mathrm{CCl}_{4}+$ methanolic stem bark extract of Ficus platyphylla $200 \mathrm{mg} / \mathrm{kg}$ for 7 days: Ballooning + (short arrow), vacuole ++ (micro vesicular steatosis) (F)(Group VI) $\mathrm{CCl}_{4}+$ methanolic stem bark extract of Ficus platyphylla $400 \mathrm{mg} / \mathrm{kg}$ for 7 days: Preserved hepatic architecture Ballooning + , vacuoles ++ Magnification $\times 100$.

+ = Low; ++ = Moderate; +++ = High

\section{DISCUSSION}

The study showed that exposure to $\mathrm{CCl}_{4}(1.5$ $\mathrm{m} / \mathrm{kg}$ ) caused an elevation in the serum AST and ALT enzymes levels and a reduction in the activities of the hepatic antioxidant liver enzymes as observed in samples obtained from the negative control group (Group II). $\mathrm{CCl}_{4}$ causes acute oxidative injury to the liver leading to oxidative damage and leakage of AST and ALT in the serum (Kaur et al., 2006; Ihedioha et al., 2019). Treatment with MEFP probably protected liver hepatocytes as levels of AST and ALT were significantly $(p<0.05)$ reduced when compared with that of the negative control group. Activities of serum ALT and AST are considered markers for the estimation of liver injury (Liu et al., 2017; Yan et al., 2019). Findings in this study suggest that MEFP treatment may have preserved the integrity of hepatic cellular membrane against $\mathrm{CCl}_{4}$ toxicity. This result is consistent with findings on hepatoprotective properties of Ficus species (Singab et al., 2010; Al-Musayeib et al., 2017; Sheidu et al., 2020). 


\section{Nigerian Journal of Basic and Applied Science (December, 2021), 29(2):67-75}

This result suggests MEFP hepato-protection sustained antioxidant enzymes activities thereby minimizing incidences of liver injury due to $\mathrm{CCl}_{4}$ exposure. Catalase and glutathione peroxidise enzymes decompose $\mathrm{H}_{2} \mathrm{O}_{2}$ to molecular oxygen $\left(\mathrm{O}_{2}\right)$ and water $\left(\mathrm{H}_{2} \mathrm{O}\right)$, thereby preventing the production of free radicals (Bachar et al., 2012; Wang et al., 2017). Similarly, the normal activities of SOD observed in samples obtained from the MEFP treatment groups show the potential of the extract to mediate the activities leading to oxidative stress such as production of superoxide ions (Kanhar and Sahoo, 2019) and other peroxides that cause cell membrane damage in $\mathrm{CCl} 4$ intoxication.

Histopathological examinations of sections of liver tissues of the negative control group show intense ballooning and necrosis of hepatocytes, an indication of $\mathrm{CCl}_{4}$ damage. However, cell architecture of sections prepared from liver of rats that received 100, 200 and $400 \mathrm{mg} / \mathrm{kg}$ treatment of MEFP compared with silymarin standard drug treated group which appears to have minimal ballooning but well preserved portal tract. The preserved histological architecture of hepatocytes in the groups that received treatment supports the biochemical findings which indicate MEFP protects against $\mathrm{CCl}_{4}$ damage. Constituents of the plant extract may have played a role in the observed hepatoprotective potential of Ficus platyphylla. The rich phenolic content of MEFP may have prevented inflammatory response and oxidative damage to hepatocytes (El-hawary et al., 2019) as observed in this study. Phytochemicals such as flavonoids with antioxidant potential and free radical-scavenging ability contribute to the hepato-protective potential of plants (Lawal et al., 2014) probably through neutralizing effects of electron transport to free radicals and activation of antioxidant enzymes (Alam and Sharma, 2020).

\section{CONCLUSION}

From the present study, the elevated levels of liver antioxidant markers and histopathological examinations of the liver suggest MEFP has a protective role against $\mathrm{CCl}_{4}$ toxicity The radical scavenging activity of the extract may partly be responsible for the hepatoprotective mechanism of the plant. Further studies are needed to isolate and characterise the active principle responsible for this activity.

\section{ACKNOWLEDGEMENTS}

The authors are grateful to Mr Ayo for preparing the slides and to all the animal house staff members for taking care of the animals before and during the study.

\section{REFERENCES}

Agada, S. A., Odama, R. I., Kenechukwu, C. O., Okang, S. O., \& Ezeh, C. O. (2020). Epidemiology of chronic liver disease in Nigeria: A review. Asian Journal of Advances in Medical Science, 2(3):1-6.

Alam, N.U.M.E.R., \& Sharma, K.R. (2020). Estimation of phenolic content, flavonoid content, antioxidant, and alpha amylase inhibitory activity of some selected plants from Siraha district Nepal. Asian Journal of Pharmaceutical and Clinical Research,13(4):18-23.

Al-Musayeib, N., Ebada, S.S., Gad, H.A., Youssef, F.S., \& Ashour, M.L. (2017). Chemotaxonomic diversity of three Ficus species: Their discrimination using chemometric analysis and their role in combating oxidative stress. Pharmacognosy Magazine, 13 (Suppl 3): S613.

Alrashood, S.T., Al-Asmari, A.K., Alotaibi, A.K., Manthiri, R.A., Rafatullah, S., Hasanato, R.M., Khan, H.A., Ibrahim, K.E., \& Wali, A.F. (2020). Protective effect of lyophilized Sapodilla (Manilkara zapota) fruit extract against $\mathrm{CCl}_{4}$-induced liver damage in rats. Saudi Journal of Biological Sciences, 27(9): 2373-2379.

Asrani, S. K., Devarbhavi, H., Eaton, J., \& Kamath, P. S. (2019). Burden of liver diseases in the world. Journal of hepatology, 70(1), 151-171. 
Ugwah-Oguejiofor et al. Methanol Stem Bark Extract of Ficus Platyphylla Protects Against...

Bachar, S.C., Mahmud, Z.A., \& Qais, N. (2012). Antioxidant and hepatoprotective activities of ethanolic extracts of leaves of Premna esculenta Roxb. against carbon tetrachloride-induced liver damage in rats. Journal of Young Pharmacist, 4(4): 228-234.

Chen, Z., Liu, F., Zheng, N., Guo, M., Bao, L., Zhan, Y., Zhang, M., Zhao, Y., Guo, W., \& Ding, G. (2019). Wuzhi capsule (Schisandra Sphenanthera extract) attenuates liver steatosis and inflammation during non-alcoholic fatty liver disease development. Biomedicine \& Pharmacotherapy, 110: 285-293.

Chindo, B.A., Jamilu, Y.U., Danjuma, N.M., Okhale, S.E., Gamaniel, K.S., \& Becker, A. (2014). Behavioral and anticonvulsant effects of the standardized extract of Ficus platyphylla stem bark. Journal of Ethnopharmacology, 154(2): 351-360.

Chindo, B.A., Schröder, H., Koeberle, A., Werz, O., \& Becker, A. (2016). Analgesic potential of standardized methanol stem bark extract of Ficus platyphylla in mice: Mechanisms of action. Journal ofEthnopharmacology, 184: 101-106.

El-hawary, S.S., Ali, Z.Y., \& Younis, I.Y. (2019). Hepatoprotective potential of standardized Ficus species in intrahepatic cholestasis rat model: involvement of nuclear factor- $\mathrm{KB}$, and Farnesoid $X$ receptor signaling pathways. Journal of Ethnopharmacology, 231: 262-274.

Goyal, A.K., Middha, S.K., \& Sen, A. (2010). Evaluation of the DPPH radical scavenging activity, total phenols and antioxidant activities in Indian wild Bambusa vulgaris" Vittata" methanolic leaf extract. Journal of Natural Pharmaceuticals, 1(1): 40-45.

Huang, X., Wang, L., Meng, M., Zhang, S., Pham, T.T.H., Jiang, L., Chen, L., Li, Y., Zhou, X., Qin, L., \& Wu, X. (2020). Extract of Averrhoa carambola L. (Oxalidaceae) roots ameliorates carbon tetrachloride- induced hepatic fibrosis in rats. Biomedical Pharmacotherapy, 121: 109516.

Ihedioha, T.E., Odo, R.I., Onoja, U.S., Nwagu, C.A., \& Ihedioha, J.I. (2019). Hepatoprotective properties of methanol leaf extract of Pterocarpus mildbraedii Harms on carbon tetrachloride-induced hepatotoxicity in albino rats (Rattus norvegicus). Journal of Complementary Medical Research, 10(4): 162-169.

Iqbal, M.J., Butt, M.S., Shehzad, A., \& Asghar, M. (2018). Evaluating therapeutic potential of coriander seeds and leaves (Coriandrum sativum L.) to mitigate carbon tetrachloride-induced hepatotoxicity in rabbits. Asian Pacific Journal of Tropical Medicine, 11(3): 209213.

Kanhar, S., \& Sahoo, A.K. (2019). Ameliorative effect of Homalium zeylanicum against carbon tetrachloride-induced oxidative stress and liver injury in rats. Biomedical Pharmacotherapy, 111: 305-314.

Kankara, S. S., Isah, A. B., Bello, A., Ahmed, A., Lawal, U. (2018). Medicinal plants used for the management of hepatic ailments in Katsina State, Nigeria. Journal of Medicinal Plants Research, 12(24): 375386.

Kaur, G., Alam, M.S., Jabbar, Z., Javed, K., \& Athar, M. (2006). Evaluation of antioxidant activity of Cassia siamea flowers. Journal Ethnopharmacology, 108(3): 340-348.

Lawal, B., Ossai, P.C., Shittu, O.K., Abubakar, A.N., \& Ibrahim, A.M. (2014). Evaluation of phytochemicals, proximate, minerals and anti-nutritional compositions of yam peel, maize chaff and bean coat. International Journal of Applied Biological Research, 6(2): 21-37.

Liu, J., Fu, Y., Zhang, H., Wang, J., Zhu, J., Wang, Y., Guo, Y., Wang, G., Xu, T., Chu, M., \& Wang, F. (2017). The hepatoprotective effect of the probiotic Clostridium butyricum against carbon 


\section{Nigerian Journal of Basic and Applied Science (December, 2021), 29(2):67-75}

tetrachloride-induced acute liver damage in mice. Food and Function, 8(11): 40424052.

Nnamudi, A. C., Onyeche, V. O., Ebohon, O., \& Eke-Ogaranya, I. N. (2020). Nigerian Medicinal Plants for the Management of Liver Diseases: A Review. European Journal of Medicinal Plants, 29-51.

Reitman, S., \& Frankel S. (1957). A colorimetric method for determination of serum glutamic oxalacetic glutamic pyruvic transminases. American Journal of Clinical Pathology, 28(1): 56-63.

Sheidu, A. R., Umar, Z. A., Abubakar, A., Ahmed, C. B., Garba, M. M., Ogere, A. I., \& Murtala, S. O. (2020). Antioxidant and Hepatoprotective Potentials of Methanol Extract of Ficus platyphylla Stem Bark Delile (Moraceae) in Wistar Rats. Tropical Journal of Natural Product Research,4(3): 91-97.

Shittu, I.I., Emmanuel, A., \& Nok, A.J. (2011). Antimalaria effect of the ethanolic stem bark extracts of Ficus platyphylla del. Journal of Parasitology Research, 2011: 1-5.

Singab, A.N.B., Ayoub, N.A., Ali, E.N., \& Mostafa, N.M. (2010). Antioxidant and hepatoprotective activities of Egyptian moraceous plants against carbon tetrachloride-induced oxidative stress and liver damage in rats. Pharmaceutical Biology, 48(11): 1255-1264.

Stanaway, J.D., Afshin, A., Gakidou, E., Lim, S.S., Abate, D., Abate, K.H., Abbafati, C., Abbasi, N., Abbastabar, H., AbdAllah, F., \& Abdela, J., (2018). Global, regional, and national comparative risk assessment of 84 behavioural, environmental and occupational, and metabolic risks or clusters of risks for 195 countries and territories, 19902017: a systematic analysis for the Global Burden of Disease Study 2017. The Lancet, 392(10159): 1923-1994.
Svistunov, A. A., Osadchuk, M. A., Kireeva, N. V., \& Osadchuk, M. M. (2018). Optimizing therapy of liver diseases not associated with viral infection. Terapevticheskii arkhiv, 90(2): 94-99.

Ugwah-Oguejiofor, C. J., \& Ugwah, O. M. (2018). Hepatoprotective activity of the aerial parts of Caralluma dalzielii N. E. Brown against Carbon tetrachloride-induced hepatotoxicity in rats. Ife Journal of Science, 20: 169-178.Ugwah-Oguejiofor, C.J., Bello, S.O., Okolo, R.U., Etuk, E.U., Ugwah, M.O., \& Igbokwe, V.U., (2011). Ficus platyphylla promotes fertility in female Rattus norvegicus Wistar strain: a preliminary study. Reproductive Biology and Endocrinology, 9(1): 1-6.

Wang, M.Y., Srinivasan, M., Dasari, S., Narvekar, P., Samy, A.L.P.A., Dontaraju, V.S., Peng, L., Anderson, G.L., \& Munirathinam, G. (2017). Antioxidant activity of Yichun Blue Honeysuckle (YBHS) berry counteracts $\mathrm{CCl}_{4}$-induced toxicity in liver injury model of mice. Antioxidants, 6(3): 50.

Yan, Y., Jun, C., Lu, Y., \& Jiangmei, S. (2019). Combination of metformin and luteolin synergistically protects carbon tetrachloride-induced hepatotoxicity: Mechanism involves antioxidant, antiinflammatory, antiapoptotic, and $\mathrm{Nrf} / \mathrm{HO}-1 \quad$ signaling pathway. Biofactors, 45(4): 598-606. 